\title{
Families and genera of mosses no longer believed to occur in sub-Saharan Africa
}

\section{Brian J. O'Shea' \& Ryszard Ochyra²}

\author{
${ }^{1141}$ Fawnbrake Avenue, London SE24, UK. E-mail: brian@oshea.demon.co.uk \\ 'Laboratory of Bryology, Institute of Botany, Polish Academy of Sciences, ul. Lubicz 46, \\ PL-31-512 Kraków, Poland. E-mail: r.ochyra@ib-pan.krakow.pl
}

\begin{abstract}
Twelve genera are excluded from the sub-Saharan Africa checklist based on evidence from literature or re-identification. Atractylocarpus, Chorisodontium, Ctenidium, Dicranodontium, Homalia, Isothecium, Lasiodontium, Meesia and Potamium are excluded as the collections belong to other genera, and Camptochaete, Phyllodrepanium and Ptychomnion are excluded because of evidence of mistaken (or no longer existing) localities. As a consequence, the following families no longer are known from Africa: Echinodiaceae, Lembophyllaceae, Phyllodrepaniaceae and Ptychomniaceae. Ectropothecium nishimurii O'Shea \& Ochyra, nom. nov. replaces Ectropothecium mauritianum (Broth.) Nishimura, hom. illeg., and Kindbergia kenyae (Dixon ex Tosco \& Piovano) O'Shea \& Ochyra, comb. nov. replaces Isothecium kenyae Dixon ex Tosco \& Piovano. Lasiodontium mieheanum Ochyra in S. Miehe \& G. Miehe, nom. nud., is a synonym of Daltonia angustifolia Dozy \& Molk. and accordingly Lasiodontium Ochyra in S. Miehe \& G. Miehe, nom. nud., must be placed in synonymy with Daltonia Hook. \& Taylor.
\end{abstract}

\section{Introduction}

The African moss checklist (O'Shea 1995) was built from checklists already produced by other authors, which in turn were mainly based on earlier literature. It will be some time before all the resulting ca. 3000 taxa can be critically examined, but in the subsequent two editions of the checklist (O'Shea 1997, 1999), attempts were made to correct some of the mistakes made in accumulating this large quantity of data. The project to create a Guide to the bryophytes of sub-Saharan Africa has required all the families and genera to be reviewed, which provides a further opportunity to review the quality of this data, and to align the families and genera used in the checklist with those to be used in the Guide. In cases where there are very few taxa or few records, it has been possible to take a critical view about their presence in Africa, and this paper reviews the evidence for 
twelve genera that are to be excluded from the Guide. In some cases evidence excluding them from Africa has already been published but overlooked in O'Shea (1999), in other cases there is no definite evidence because the necessary collections are missing, but nevertheless there is a strong balance of probabilities that the taxa do not occur in Africa; all twelve taxa will be represented by just a comment in future checklists. Any reference in this document to the 'checklist' refers to O'Shea (1999) unless stated otherwise.

\section{Genera to be excluded}

\section{Atractylocarpus (Dicranaceae)}

The African species of Atractylocarpus have been transferred to Metzleria. See Frahm (2000).

\section{Camptochaete (Lembophyllaceae)}

Prior to version 3 of the checklist (O'Shea 1999), there were two species of Camptochaete on the list: $C$. fallax (Renauld \& Cardot) Renauld and $C$. ramulosa (Mitt.) A.Jaeger. The latter was removed in version 3 because of an error that occurred in Born et al.'s (1993) checklist for Central Africa, where records from Demaret (1940) and Demaret \& Leroy (1949) for Porotrichum ramulosum (Mitt.) Dusen were mistaken for $P$. ramulosum (Mitt.) Mitt. The confusion is easy to understand, as the combination $P$. ramulosum has been made on three different occasions, twice by Mitten:

Porotrichum ramulosum (Mitt.) Mitt., Trans R. Soc. Victoria 19: 84. 1882 (Isothecium ramulosum Mitt., Kew. J. Bot. 8: 263. 1856 (三Camptochaete ramulosa (Mitt.) A.Jaeger, Ber. S. Gall. Naturw. Ges. 1875-76: 309. 1877 (Ad. 2: 213))

Porotrichum ramulosum (Mitt.) Mitt., J. Linn Soc. Bot. 33: 315. 1886 (Neckera ramulosa Mitt., J. Linn. Soc. Bot. 7: 160. 1863 (=Porotrichum cameruniae Dixon, fide Dixon, J. Bot. 75: 123. 1937))

Porotrichum ramulosum (Mitt.) Dusén, Kongl. Svenska Vetensk. Acad. Handl. 28(2): 42.1895 (Neckera ramulosa Mitt.)

Born et al. (1993) should have referred to the taxon based on Neckera ramulosa, not Isothecium ramulosum, and so Camptochaete ramulosa (now a synonym of $C$. deflexa (Wils.) A.Jaeger) can be excluded from the African list. The full synonymy for $C$. deflexa can be seen in Tangney (1997). Porotrichum ramulosum and $P$. cameruniae are now synonyms of $P$. quintasii (De Sloover 1983).

In his revision of Camptochaete, Tangney (1997) called C. fallax, recorded only for Madagascar, an 'uncertain species' and stated that: "Not having seen any material of this species, I have no knowledge of its relation to Camptochaete", and in addition, Madagascar falls outside the geographic range of the genus as he understood it. The Madagascar record was from Diego Suarez, near the north tip of the island, (now called Antserañana, $12^{\circ} 19^{\prime} \mathrm{S} 49^{\circ} 17^{\prime} \mathrm{E}$ ), collected by Chenagon in 1890, and was published first in Renauld \& Cardot (1897) and the same information was then repeated in Renauld (1898) and Renauld \& Cardot (1915); in addition, the latter reference also has an illustration of the taxon. Although the illustration looks quite like Camptochaete, the authors comment on the relatively long and narrow leaf cells, and the denticulate leaf margins, which would probably discount Camptochaete. Tangney (1997) applied to 23 herbaria for loans, but no collections of this taxa were provided. PC holds the herbaria of both Renauld and Cardot, and were amongst the herbaria contacted by Tangney (1997). As no specimen is available, and as there might be doubt as to the correct assignation to genus, and as Madagascar would be significantly outside the taxon's present range, the taxon is excluded until further evidence is available.

\section{Chorisodontium (Dicranaceae)}

Chorisodontium is an austral pan-temperate genus distributed mainly in South America from Tierra del Fuego to the northern Andes and extending to the Subantarctic and the northern maritime Antarctic. One species, Chorisodontium falcatum Magill, was described from the Cape area of South Africa and Îles Kerguelen (Magill 1981), but this species is regarded by Frahm (1989) as identical with Platyneurum laticostatum (Cardot) Broth., now treated as $P$. praealtum (Ochyra \& Bednarek-Ochyra 1997). Examination of the 
original material of $C h$. falcatum confirmed that this name must go into synonymy with $P$. praealtum. Accordingly, in the moss flora of Africa the genus Chorisodontium is replaced by the predominantly southern South American genus Platyneurum.

\section{Ctenidium (Hypnaceae)}

Three species of Ctenidium have been reported for tropical Africa, and included in all three versions of the checklist. However, $C$. mauritianum Broth. and C. squarrifolium (Broth.) Broth. were transferred to Ectropothecium by Nishimura (1985) in his revision of Ctenidium, and non-type material of both species present in $\mathrm{BM}$ also belongs to Ectropothecium. The third species, C. floribundoides Dixon ex Tosco \& Piovano, was not mentioned by Nishimura, presumably because Tosco and Piovano's (1956) paper was overlooked by Wijk et al. (1959-1969) when compiling Index Muscorum. Dixon's herbarium is held in BM, but $C$. floribundoides is not present in it, and loans are not made from TOR (where Tosco \& Piovano's collections are held). Nishimura (1985) does not consider Ctenidium to occur in Africa, although phytogeographically there is no reason why it should not be present. However, the description and illustration in Tosco \& Piovano (1956) suggest that $C$. floribundoides may not be a Ctenidium, particularly the lack of any leaf decurrency. Until a specimen is located or expert attention is given to Tosco \& Piovano's paper, it seems wise to exclude Ctenidium from the African flora.

As one of Nishimura's new names in Ectropothecium was invalid, the taxon is renamed here:

Ectropothecium nishimurii O'Shea \& Ochyra, nom. nov. pro Ectropothecium mauritianum (Broth.) N.Nishim., J. Hattori Bot. Lab. 58: 75. 1985, hom. illeg. [non E. mauritianum Renauld \& Cardot in Paris, Ind. Bryol. Suppl. 137. 1900.] based on Ctenidium mauritianum Broth. in Voeltzkow, Reise Ost Afr. 3: 62, t. 9, f. 12, 1908. Type: Mauritius (Mascarene Isles), 1904, Voeltzkow s.n. (holotype and isotype, H-BR), fide Nishimura 1985: p. 75.

\section{Dicranodontium (Dicranaceae)}

Dicranodontium is mainly holarctic. Three species were described from Central and East Africa and Madagascar (Potier de la Varde 1950, 1954; Taylor \& Potier de la Varde 1954), of which $D$. interruptum proved to be synonymous with Bryohumbertia filifolia, D. tanganyikae was identical with Campylopus flexuosus and D. humilis was regarded as a species of Blindia (Frahm 1997).

\section{Homalia (Neckeraceae)}

After the transfer of Homalia pygmaea Broth. to Symphyodon (as S. pygmaeus (Broth.) S.He \& Snider) by He \& Snider (1992, 2000), H. subexigua Müll.Hal. in Geh. was the only member of this genus on the checklist. Presumably because it was a nomen nudum, it was not mentioned in He's (1997) revision of Homalia, but a specimen with this name was found in BM, filed under Homaliodendron exiguum (Bosch \& Sande Lac.) M.Fleisch. The original collection in Mauritius was made by Robillard in 1876, and was published by Geheeb (1878) with Müller's manuscript name, but no description. The BM collection details are as follows: Mauritius. Pouce Mts., 1878, Balfour s.n. ex herb Mitten (BM). H. N. Dixon makes the following comments on the sheet: "This [Homalia subexigua] appears to be unpublished. No doubt it is H[omalia] Valentinii, which appears to be scarcely separable from $H$. exigua." H. valentinii Besch., fide Fleischer (1908), is now a synonym of Homaliodendron exiguum: the Balfour specimen is identical to $H$. exiguum. H. exiguum is already known in Africa from Mauritius, as well as Réunion, Madagascar, Comores and Tanzania, and is widespread in tropical and sub-tropical Asia, Oceania and Australasia. As no description has ever been published of $H$. subexigua, it is likely that this collection has been named with reference to the original collection; however, without seeing the original collection it is not possible to suggest synonymisation, but serious doubt is certainly cast on the status of the taxon, and it should be excluded from the African list.

\section{Isothecium (Echinodiaceae)}

The genus Isothecium Brid. is represented in subSaharan Africa only by a single species, I. kenyae Tosco \& Piovano. This name was proposed by 
H. N. Dixon for the plant collected in 1914 by G. Balbo in Central Kenya, but it remained unpublished as a typical herbarium name until Tosco \& Piovano (1956) validated it after examination of the specimen preserved in the African Bryological Herbarium of the Consolata Society for Foreign Missions in Turin. A duplicate of this collection is preserved in the Dixon herbarium (now in BM) and it has been available for investigation.

In a brief taxonomic discussion Tosco \& Piovano (1956) stated that although Dixon admittedly attributed this moss to Isothecium, it shows closer alliance with Brachythecium Bruch, Schimp. \& W.Gümbel or Homalothecium sericeum (Hedw.) Bruch, Schimp \& W.Gümbel in its leaf areolation and overall aspect. Examination of the type material indeed confirms this observation. The leaf areolation of Isothecium kenyae is totally unlike that of other species of Isothecium in which the distinct alar groups consist of small, opaque, densely chlorophyllose cells with strongly incrassate walls forming yellowing to brownish auricles. In addition, the upper cells in Isothecium are rhomboidal to narrowly rhomboidal, thick-walled, becoming shorter at the margins and towards the apex. In contrast, in I. kenyae the basal cells are quadrate to short-rectangular, pellucid, with moderately thick to incrassate and porose, yellow-coloured walls, especially well seen on branch leaves (Fig. 1.6-7). They form a distinct band sharply set off from the adjacent laminal cells. The upper cells are thin-walled, long rhomboidal to oblong-linear, with shortly fusiformly narrowed ends. This leaf areolation indicates close alliance of I. kenyae with the brachythecioid mosses rather than with Isothecium.

When describing Isothecium kenyae, Tosco \& Piovano (1956) overlooked one important detail of this new species, namely a marked leaf dimorphism (Fig. 1.1-5). The stem leaves are abruptly long acuminate from a triangular to ovatecordate base. They are erect-spreading with often spreading apices and are long decurrent (Fig. 1.6). The costa ends about mid-leaf and does not project dorsally as a spine. The branch leaves are oblong-ovate, gradually tapering into the long acumen and are not decurrent (Fig. 1.7).

The only genus of the Brachytheciaceae which has markedly differentiated leaves is Kindbergia Ochyra. Because Isothecium kenyae fits well the concept of this genus, the following transfer is necessary:

Kindbergia kenyae (Dixon ex Tosco \& Piovano) O'Shea \& Ochyra, comb. nov. Basionym: Isothecium kenyae Dixon ex Tosco \& Piovano, Allionia 3(1): 142, f. 21. 1956. Type: Kenya (Central Prov.), Isanguni: foresta a $2000 \mathrm{~m}$. s.l.m., su rocce (leg. G. Balbo, 1 ott. 1914) [Holotype: TOM (not seen); isotype: "Herb. H. N. Dixon. Ref. No. 341 Isothecium Kenyae Dix. sp. nov. Rocks, Isanguni, Kenya Colony; 2000 m. Coll. G. Balbo 1 Oct. 1914, comm. P. G. Piovano type" (BM!)].

In sub-Saharan Africa the genus Kindbergia is represented by a single species, $K$. africana (Herz.) Ochyra which is widely distributed in the Central and East African volcanic area. It is a montane species occurring at an elevation of $1900-4000 \mathrm{~m}$ (Kis 1985; O'Shea 1999; Ochyra 1997b). It differs from K. kenyae in several characters including the smaller size of the plants and the shorter, erect-spreading and sharply and coarsely serrulate branch leaves, up to $1.0 \mathrm{~mm}$ long, with thin-walled basal cells. In contrast, the branch leaves in K. kenyae are up to $1.8 \mathrm{~mm}$ long, closely appressed and finely serrulate at margins and have basal cells mostly with incrassate yellow walls.

This taxonomic conclusion results in the exclusion of the genus Isothecium from the moss flora of sub-Saharan Africa. Nonetheless, this genus is present on mainland Africa and three species have been recorded from the area north of the Sahara, namely I. alopecuroides (Dubois) Isov. and I. myosuroides Brid. from Algeria and Morocco and I. maroccanum Thér. \& Meyl. from Morocco (Ros et al. 1999).

The familial placement of Isothecium has been unstable and the genus was shifted from family to family of pleurocarpous mosses including the Lembophyllaceae and Brachytheciaceae. We follow here the suggestion of Hedenäs (1992) who placed Isothecium in the Echinodiaceae, unfortunately without giving the reasons for this transfer. 


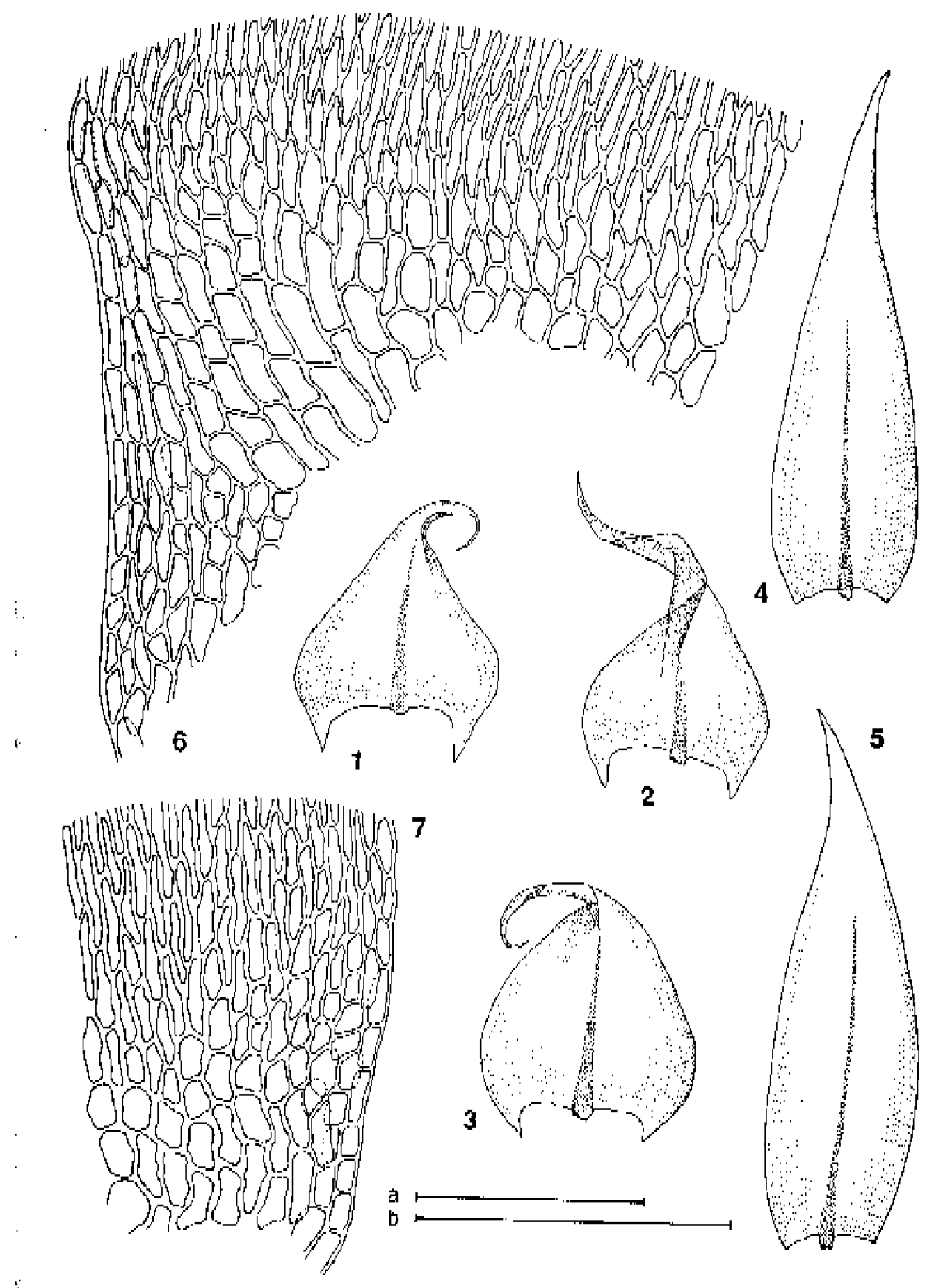

Fig. 1: Kindbergia kenyae (Dixon ex Tosco \& Piovano) O'Shea \& Ochyra. 1-3: stem leaves; 4-5: branch leaves; 6: basal and alar cells of stem leaf; 7: basal cells of branch leaf. (All drawn from Balbo s.n., 1 Oct 1914, isotype of Isothecium kenyae, BM). Scale bars: a: $1 \mathrm{~mm}$ (1-5); b: $100 \mu \mathrm{m}(6-7)$. 


\section{Lasiodontium (Bryaceae)}

In the list of mosses collected in the Bale Mountains in Ethiopia Miehe \& Miehe (1994) published the name Lasiodontium mieheanum Ochyra. This provisional name of a new species and genus of the Bryaceae has never been validly published and the subsequent reexamination of the material revealed that it represented Daltonia angustifolia Dozy \& Molk., a species and genus which had not hitherto been recorded from Ethiopia. Accordingly, the invalidly published generic name Lasiodontium Ochyra must go into synonymy with Daltonia Hook. \& Taylor and $L$. mieheanum becomes a synonym of $D$. angustifolia.

Daltonia angustifolia Dozy \& Molk.

= Lasiodontium mieheanum Ochyra in Miehe \& Miehe, Eric. For. Heathl. Bale Mts S Ethiopia: 168. 1994. Original material: ETHIOPIA. Bale Mts., above Goba, 6 ${ }^{\circ} 54^{\prime}$ N, 3956'E, alt. 3450-3500 m; upper montane PhilippiaHagenia forest on $30-40^{\circ}$ steep rocky upper slope with relatively little human disturbance; accompanying ground moss; 4 Mar 1990, $S$. \& G. Miehe 3290a (KRAM), syn. nov. .

\section{Meesia (Meesiaceae)}

The only species recorded for the area is Meesia kenyae P.de la Varde. Ochyra (2000) considered it to be conspecific with Ceratodon purpureus (Hedw.) Brid.

\section{Phyllodrepanium (Phyllodrepaniaceae)}

Schwaegrichen (1816) first mentioned Phyllodrepanium falcifolium (Schwägr.) Crosby (the only species in the family) as a plant of Réunion, although Bescherelle (1878) expressed serious doubts about this, and Crosby (1970) gave additional reasons why it should be excluded from Africa. Nevertheless, Crosby et al. (1983) included it in their list of mosses of the East African islands, and it subsequently appeared in the African moss checklist (O'Shea 1995, 1997, 1999). Crosby's (1970) argument is fully endorsed here, and the moss is thus excluded from the African moss checklist.

\section{Potamium (Sematophyllaceae)}

Bryophytes that occur in areas subject to inundation are notable for their high degree of variation, and this is also true in Sematophyllaceae. Potamium sanctae-mariae (Besch.) Broth., Nat. Pfl. 1(3): 1107. 1908 (Basionym: Pterogoniella sanctae-mariae Besch., Ann. Sci. Nat. Bot., sér 6 10: 260. 1880.) was described from the island of Sainte-Marie (now Nosy Boraha) off the E coast of Madagascar from a Boivin collection of 1850, 'sur les racines de Manguieres'. Renauld \& Cardot (1890) discussed the two specimens of this taxon loaned to them by Bescherelle, pointing out that the two collections represented two different species: Boivin's collection that agreed with the description of Pterogoniella (= Potamium) sanctae-mariae, and a Marie collection that was Pterogoniella diversifolia (= Meiothecium diversifolium). Buck (1990) found that Bescherelle's herbarium (in BM) now contained only Marie's M. diversifolium. However, Buck (1990) repeats Renauld \& Cardot's (1890) assertion that $P$. sanctae-mariae had only a single peristome, which would exclude it from Potamium/ Sematophyllum and probably place it in Meiothecium. It should be noted that Bescherelle (1880) described an external peristome and then added 'interni fugaces?', giving some possibility of doubt about placement in Potamium, and the balance of possibilities is, as Buck states, that the collection was a Meiothecium. Buck (1990) therefore ignored it in his analysis of Potamium (which he reduced to one species). The genus Potamium was revised by Florschütz-de Waard (1992), and treated as a genus of two species, restricted to tropical South America. Florschützde Waard (1992) rejected Buck's (1990) analysis of the genus, but accepted his statement concerning $P$. sanctae-mariae. It seems likely that if the original specimen is ever found that it will prove to be something other than a Potamium, and the genus can thus be removed from the list.

\section{Ptychomnion (Ptychomniaceae)}

This genus has been reported twice from Africa and its adjacent Indian Ocean islands. Bridel (1827) mentioned Ptychomnion aciculare (Brid.) Mitt. (as Hypnum aciculare Brid.) from Mauritius on the basis of the specimen collected by Bory de St. Vincent during his year-long stay in Mauritius and Réunion from May 1801. According to Dorr (1997) he did not collect 
elsewhere during this period, and returned directly to France at the end of his visit. The taxon thus seems to be a correctly assigned collection for the island, but the species has not been rediscovered there since. No voucher collection which could confirm this record is present in the Bridel herbarium at B. Ptychomnion aciculare is a large and distinctive plant, and Mauritius has been explored in some detail by bryologists in the last two centuries, during which period there have been significant changes in the island's vegetation, so there must be a strong suspicion that the plant does not now occur in Mauritius.

Shaw (1878) recorded Ptychomnion aciculare from mainland Africa on the basis of the collection he had made in 1869 on the Katberg in the Cape Colony. Sim (1926) discredited this report (although he did not indicate the correct identification of the collection) and excluded this species from the bryophyte flora of Southern Africa, as also did Magill \& Schelpe (1979) in their checklist of the bryophytes of this region. Also, no specimens of this species from Africa have been located by Hattaway (1984) in his unpublished revision of the Ptychomniaceae.

Ptychomnion is an oligotypic austral genus with a wide pan-temperate distribution and only rarely deeply penetrating into the tropics. $P$. aciculare is an Australasian species widespread in eastern Australia, New Zealand and Tasmania and extending to North Borneo and the Society Islands in the Pacific and its occurrence in mainland Africa is rather improbable. Nonetheless, the discovery of this genus, for example on Réunion, is quite possible since another species of this genus, $P$. densifolium (Brid.) A.Jaeger is very common on the subantarctic islands, namely Marion and Prince Edward Islands and Îles Crozet, as well as on Tristan da Cunha, and sometimes austral cooladapted mosses penetrate into this island, for example Racomitrium membranaceum (Mitt.) Paris, but for now Ptychomnion should be best removed from the list of African moss genera.

\section{Acknowledgements}

Thanks to Jan-Peter Frahm for input on Atractylocarpus, Chorisodontium and Dicranodontium, to Len T. Ellis for making available the type of Isothecium kenyae for examination, and to Halina Bednarek-Ochyra for the illustrations of Kindbergia kenyae.

\section{References}

Bescherelle, E. 1878. Florule bryologique de la Réunion et des autres iles austro-africaine de l'océan Indien. Annales des Sciences Naturelles, Botanique série 6, 9: 291-380.

Bescherelle, E. 1880. Florule bryologique de la Réunion et des autres iles austro-africaine de l'océan Indien (Deuxième partie). Annales des Sciences Naturelles, Botanique série 6, 10: 233-332.

Born, S., Frahm, J.-P. \& Pócs, T. 1993. Taxonomic Results of the BRYOTROP Expedition to Zaire and Rwanda 26. A new checklist of the mosses of Central Africa. Tropical Bryology 8: 223-273.

Bridel, S. E. 1827. Bryologia universa seu systematica ad novam methodum dispositio, historia et descriptio omnium muscorum frondosorum hucusque cognitorum cum synonymia ex auctoribus probatissimis. Volumen secundum. Lipsiae.

Buck, W.R. 1990. Contributions to the moss flora of Guyana. Memoirs of the New York Botanical Garden 74: 184-196.

Crosby, M.R. 1970. Some remarks on the genus Drepanophyllum Schwaegr. Revue Bryologique et Lichénologique 37: 345-353.

Crosby, M.R., Schultze-Motel, U. \& SchultzeMotel, W. 1983. Katalog der Laubmoose von Madagaskar und den umliegenden Inseln. Willdenowia 13: 187-255.

De Sloover, J.L. 1983. Note de bryologie africaine. XII. Porotrichum et Porothamnium. Bulletin du Jardin Botanique de Belgique 53: 97-152.

Demaret, F. 1940. Prodrome des bryophytes du Congo Belge et du Ruanda-Urundi. I. Musci.Bulletin du Jardin Botanique de l'État 16: 21-104.

Demaret, F. \& Leroy, V. 1949. Récoltes bryologiques de M. R. Germain au Congo Belge. Bulletin $d u$ Jardin Botanique de l'État 19: 359-370.

Dorr, L.J. 1997. Plant Collectors in Madagascar and the Comoro Islands. Richmond: Royal Botanic Gardens, Kew.

Fleischer, M. 1908. Grundlagen zu einer Monographie der Gattung Stereohypnum (Hpe.) (Microthamnium Mitt. olim.) Hedwigia 47: 271- 
299.

Florschütz-de Waard, J. 1992.A revision of the genus Potamium (Musci: Sematophyllaceae). Tropical Bryology 5: 109-121.

Frahm, J.-P. 1989. The genus Chorisodontium (Musci, Dicranaceae) in the neotropics. Tropical Bryology 1: 11-24.

Frahm, J.-P. 1997. A taxonomic revision of Dicranodontium (Musci).Annales Botanici Fennici 34: 179-204.

Frahm, J.-P. 2000. New combinations in the genus Atractylocarpus and Metzleria. Tropical Bryology 18: 115-117.

Geheeb, A. 1878. Sur une petite collection de mousses nouvelles de l'Isle Maurice.Revue Bryologique 5: 59.

Hattaway, R. A. 1984. A monograph of the Ptychomniaceae (Bryopsida). Ph.D. thesis, The Pennsylvania State University, $310 \mathrm{pp}$.

He, S. 1997. A revision of Homalia (Musci: Neckeraceae). Journal of the Hattori Botanical Laboratory 81: 1-52.

He, S. \& Snider, J. 1992. A preliminary survey of the moss genus Symphyodon (Symphyodontaceae), Musci. Bryobrothera 1: 283-287.

He, S. \& Snider, J. 2000. A taxonomic revision of Symphyodon (Musci: Symphyodontaceae). The Bryologist 103: 52-81.

Hedenäs, L. 1992. Flora of Madeiran pleurocarpous mosses (Isobryales, Hypnobryales, Hookeriales). Bryophytorum Bibliotheca 44: 1-165.

Kis, G. 1985. Mosses of south-east tropical Africa . Vácrátót: Institute of Ecology and Botany of the Hungarian Academy of Sciences.

Magill, R. E. 1981. Sphagnaceaeae - Grimmiaceae. In: Leistner, E. O. (ed.), Flora of southern Africa which deals with the territories of South Africa, Transkei, Lesotho, Swaziland, Bophuthatswana, South West Africa/Namibia, Botswana and Venda. Bryophyta. Part 1. Mosses. 2, pp. i-xv + 1-291. Pretoria: Botanical Research Institute.

Magill, R. E. \& Schelpe, E. A. 1979. The bryophytes of Southern Africa. An annotated checklist.Memoirs of the Botanical Survey of South Africa 43: 1-39.

Miehe, G. \& Miehe, S. 1994. Ericaceous forest and heathlands in the Bale Mountains of South Ethiopia. Ecology and man's impact. Hamburg: Stiftung Walderhaltung in Afrika and Bundesforschungsanstalt für Forst- und Holzwirtschaft.

Nishimura, N. 1985. A revision of the genus Ctenidium. Journal of the Hattori Botanical Laboratory 59: 1-82.

Ochyra, R. 1997. Eurhynchiella decurrens is conspecific with Kindbergia africana (Musci, Brachytheciaceae). Fragmenta Floristica et
Geobotanica 42: 579-582.

Ochyra, R. 2000. Does the family Meesiaceae (Musci) occur in Africa? Cryptogamie, Bryologie. (in press)

Ochyra, R. \& Bednarek-Ochyra, H. 1997. The type specimen of Leptotrichum praealtum (Musci, Ditrichaceae). Fragmenta Floristica et Geobotanica 42: 567-570.

O'Shea, B.J. 1995. Checklist of the mosses of subSaharan Africa. Tropical Bryology 10: 91-198.

O'Shea, B.J. 1997. Checklist of the mosses of subSaharan Africa (version 2, 7/97). Available from: http://www.oshea.demon.co.uk/tbr.htm

O'Shea, B.J. 1999. Checklist of the mosses of subSaharan Africa (version 3, 11/99). Tropical Bryology Research Reports 1: 1-133.

Potier de la Varde, R. 1950. Espèces et variétés nouvelles récoltées à Madagascar par $\mathrm{M}$. le Professeur H. Humbert au cours de son 6 et de son $7^{\text {e }}$ voyage. Revue Bryologique et Lichénologique 19: 145-154.

Potier de la Varde, R. 1955. Mousses récoltées par M. le Dr. Olov Hedberg, en Afrique orientale, au cours de la mission suédoise de 1948. Arkiv för Botanik Serie 2, 3(8): 125-204.

Renauld, F. 1898. Prodrome de la flora bryologique de Madagascar, des Mascareignes et des Comores . Monaco: Imprimerie de Monaco.

Renauld, F. \& Cardot, J. 1890. Musci exotici novi vel minus cogniti, I. Bulletin de la Société Royale de Botanique de Belgique 29: 161-186.

Renauld, F. \& Cardot, J. 1897. Musci exotici novi vel minus cogniti, VIII. Bulletin de la Société Royale de Botanique de Belgique 35: 299-325.

Renauld, F. \& Cardot, J. 1915. Mousses. In: Grandidier, A. \& Grandidier, G. (eds.). Histoire, physique, naturelle et politique de Madagascar39: $1-562$.

Ros, R. M., Cano, M.J. \& Guerra, J. 1999.Bryophyte checklist of Northern Africa.Journal of Bryology 21: 207-244.

Schwaegrichen, F. 1816. Species Muscorum Frondosorum. Supplementum Primum. Sectio Posterior. Leipzig.

Shaw, J. 1878. Catalogue of the mosses of the Cape Colony on the basis of Müller's „Synopsis muscorum frondosorum", with short descriptions of new species. The Cape Monthly Magazine 17: 311-320, 376-383.

Sim, T. R. 1926. The Bryophyta of South Africa comprising Sphaerocarpales, Marchantiales, Jungermanniales, Anthocerotales, Sphagnales, Andreaeales, Polytrichales, Bryales.Transactions of the Royal Society of South Africa 15: i-iii + 1475 .

Tangney, R.S. 1997. A taxonomic revision of the genus 
Camptochaete Reichdt., Lembophyllaceae (Musci). Journal of the Hattori Botanical Laboratory 81: 53-121.

Taylor, J. \& Potier de la Varde, R. 1954. A contribution to the moss flora of tropical Africa. Kew Bulletin 1954(4): 505-516.

Tosco, U. \& Piovano, G. 1956. Le raccolte briologiche dei Missionari della Consolata in Etiopia, Kenya e Tanganyika (I). Allionia 3: 111-186.

Wijk, R. van der, Margadant, W.D. \& Florschütz,

P.A. 1959-1969. Index Muscorum. Utrecht: IAPT. 
